\title{
FILOSOFIE JE NAPSANÁ V PŘEVELIKÉ KNIZE VESMÍRU. PO ČTYŘECH STOLETÍCH VYŠEL GALILEU゚V PRUBÍR̆
}

Galilei, Galileo. Prubiřr. Překlad Markéta Ledvoňová a Jana Malá. Odborná spolupráce a komentáře Markéta Ledvoňová, Daniel Špelda a Vladimír Štefl. Praha: Togga, 2020. 354 stran.

\section{VOJTĚCH BERNACIK}

email / vojtech.bernacik@email.cz

Galileův Prubiř (1623) vychází v nedávno založené a již završené edici Fontes Scientiae (Togga, spoluvydavatel Masarykova univerzita), pod jejíz hlavičkou stihl brněnský historik a filosof vědy Daniel Špelda v obdivuhodně rychlém sledu vydat výbory z děl Newtona, Keplera, Bernoulliho a Rozhovory o mnohosti světů od Bernarda de Fontenella. ${ }^{1}$ Českému čtenáři se tak nabízí př́ležitost detailněji nahlédnout do počátků moderní vědy a intimněji poznat náročný proces formulace dnes mnohdy automaticky přijímaných závěrů či postřehů týkajících se fyzikálních zákonů. ${ }^{2}$

Galileo Galilei patří bezesporu mezi vědce, jejichž život a aktivity mapuje bohatá literatura, přičemž zájem o dějiny tzv. vědecké revoluce 17. století ani dnes neustává. Vezmeme-li v potaz, že první životopis Galileiho napsal již jeho žák Vinzenzo Viviani (1654), pak si můžeme snadněji představit, o jakou řádku děl se jedná.

Galileovi náleží v dějinách vědy poměrně výsadní postavení. Uplatnila se na něm spousta různorodých př́stupů a dobových tendencí, a tak se můžeme setkat s Galileem jakožto prvkem kumulativního procesu dějin, kdy za jeho bezprostředního předchůdce platí Giordano Bruno (Heller), nebo společně s pozitivistickou historiografií nahlížet na 17. století jako na období induktivních př́stupů, díky nimž vědci jako Galileo získávali univerzální zákony z nahromaděných faktů (Whewell).

Známým a značně oblíbeným je obraz Galilea a Bruna jako bojovníků pravdy proti církvi coby konzervativnímu strážci mýtů (Draper, White),

\footnotetext{
${ }^{1}$ Galileo Galilei, Prubiŕ (Praha: Togga, 2020).

${ }^{2}$ Počeštěn byl nedávno také Galileův slavný Hvězdný posel (1610) spolu s Keplerovou odpovědí ve svazku Galileo Galilei a Johannes Kepler, Hvězdný posel / Rozprava s Hvězdným poslem (Příbram: Pistorius \& Olšanská, 2016).
}

(C) (†) Toto dílo podléhá licenci Creative Commons Attribution 4.0 International. 
jiné interpretace však toto pojetí odmítají. Pietro Redondi tak kupř́íkladu upozornil na to, že Galileo měl mocné církevní ochránce, s nimiž udržoval čilé styky a kteří ho dlouhou dobu ochraňovali (svědčí o tom do jisté míry i představovaný svazek). Maurice A. Finocchiario podobný postoj podpořil pojetím, z něhož jasně vyplývá, že je celý kontext Galileiho díla mnohem komplikovanější a že jej nelze redukovat na souboj vědy a víry.

Velkým galileovským historiografem byl i u nás hojně překládaný francouzský historik a filosof vědy Alexandre Koyré. Rovněž on upozornil na to, že by dějiny vědy neměly být vnímány jako souhrn úspěchů jedněch a selhání druhých, a hledal obecnější příčiny významných objevů. Pro 17. století je viděl např. ve změnách metafyzického chápání přírodního řádu. Náboženství tedy nemuselo stát velkým vědcům $v$ cestě, ale mohlo mít produktivní úlohu. Koyré upozornil na to, že změny ve vnímání světa souvisí i s proměněným př́stupem $\mathrm{k}$ aristotelským výkladům (i $\mathrm{k}$ tomu poslouží recenzovaný svazek jako vhodná ilustrace). Podle Koyrého byli velcí novověcí vědci ve své podstatě platoniky, jelikož ve svých experimentech pracovali $\mathrm{s}$ ideálními tělesy v ideálním abstraktním světě.

Do historického a intelektuálního kontextu je české vydání Galileova Prubiřre ${ }^{3}$ uvedeno filosofickým textem Daniela Špeldy ${ }^{4}$ a astronomickým výkladem některých jevů, na něž lze v tomto textu narazit, jehož autorem je Vladimír Štefl. ${ }^{5}$ Galileův polemický dopis Prubiř přeložila z italštiny Markéta Ledvoňová, která se mu věnovala již v rámci své disertace. Latinské části textu pak přeložila Jana Malá.

Daniel Špelda začíná svou úvodní studii citací ze slavné pasáže Prubiře, jež je považována za ikonické vyjádření proměny vědy úzce opřené o starověké dědictví ve vědu moderní: „Filosofie je napsaná v této převeliké knize (mám na mysli vesmír), kterou máme neustále otevřenou před očima, ale není možné jí porozumět, pokud se člověk před tím nenaučí porozumět jazyku a poznat znaky, v nichž je napsána. Je napsána $v$ jazyce matematiky a jejími znaky jsou trojúhelníky, kružnice a další geometrické tvary. Bez těchto prostředků není v lidských možnostech pochopit z ní jediné slovo; být

\footnotetext{
${ }^{3}$ Jak uvádí Vladimír Štefl (81-82), název Il Saggiatore Galileo zvolil v př́mé reakci na Grassiho (ř́mský astronom, s nímž Galileo vedl polemiku) spis Váha astronomická a filosofická (Libra astronomica ac philosophica). Grassi v něm „váži“ některá témata, jimiž se v předcházejícím spise věnovaným kometám zabývá Mario Guiducci (Galileův žák) společně s Galileem. Saggiatore je pak váhou zlatníků, takže Galileo naznačuje, že Grassi váží hrubě, obyčejnou váhou, kdežto on natolik jemně, že mu pravda proklouznout nemůže - váží zlato pravdy.

${ }^{4}$ Daniel Špelda, „Filosofické motivy v Prubírii,“in Galilei, Prubír, 11-56.

${ }^{5}$ Vladimír Štefl, „Dalekohled a komety v Prubírii,“ in Galilei, Prubír, 57-93.
} 
bez nich znamená marně bloudit temným labyrintem.“ (11) Galileův Prubiŕ, ačkoliv se nejedná o nejvýznamnější dílo florentského vědce, podrobněji ukazuje, co všechno se muselo změnit, aby se vnímání vesmíru začalo opírat o matematické veličiny. Dovoluje čtenáři nahlédnout způsob myšlení nejen samotného Galilea, ale rovněž dalších vědců, z nichž je v kontextu spisu nejvýznamnější jezuitský astronom Orazio Grassi, který je jeho adresátem.

Galileo však nepolemizuje přímo s Grassim, ale s jeho vymyšleným žákem Sarsim. Ani Grassi totiž ve svých polemikách nereagoval př́ímo na Galilea, nýbrž na Galileova (skutečného) žáka Guiducciho, za jehož mnohými závěry z pozorování komet ovšem stál právě Galileo. Ten se tak v Prubiři může tvářit, že neobhajuje ani tak sebe jako svého žáka.

Jádro tehdejších sporů mezi učenci tkvělo v několika vzájemně se prolínajících skutečnostech: (1) Někteří astronomové zpochybňovali závěry vycházející z pozorování prostřednictvím dalekohledu; (2) dalekohled výrazně přispěl $\mathrm{k}$ rozpravě nad aristotelsko-ptolemaiovskou představou o světě; (3) světem vzdělanců tehdy rezonoval poměrně nový Koperníkův systém doprovozený kompromisním modelem Tychona Brahe, $\mathrm{k}$ němuž se ve výsledku přikláněla část jezuitských astronomů; (4) stěžejní otázkou Prubiř je však podstata komet společně se snahou určit jejich vlastnosti. Právě tady se všechny zmíněné problémy protnuly a právě tady rovněž spočívala podstata Galileova sporu s Grassim. Záběr debaty, která se vedla kolem umístění komet, byl natolik široký, že vedl k novému teoretickému uspořádání Sluneční soustavy.

Jak Daniel Špelda na několika místech svého úvodu zdůrazňuje, je pro současného čtenáře zajímavé sledovat omyly jedné $\mathrm{z}$ ikon dnešního vědeckého světa. Galileo totiž obhajoval hypotézu, jež se ještě z velké části opírala právě o Aristotelovu kosmologii. A tak paradoxně ten, kdo učinil výrazný krok k oproštění vědy od myšlenek brzdících další rozvoj v pojímání vesmíru, zůstával do jisté míry v zajetí starých koncepcí. Četba Prubíre nám tedy dovoluje zúčastnit se stěžejního přerodu, stát se na chvíli svědky proměny v nahlížení základních vztahů ve vesmíru.

Ukažme si některé argumenty, jež obě strany představily a kterými se mimo samotný pramen zabývají rovněž úvodní studie recenzovaného svazku. Začněme právě u komet. Grassi obhajoval názor, že komety nemohou být sublunárními tělesy, čímž vystoupil proti aristotelské kosmologii. Komety podle Grassiho nejsou jevem provázejícím hoření pozemských výparů v atmosfére, chovají se spíše jako dočasné planety a pohybují se po oválných drahách. Je-li tomu ale tak, pak se nemůže jednat o výpary (Aristoteles) ani o světelný efekt Slunce ozařujícího plynné průhledné těleso, 
jehož hustota by byla větší než hustota okolí (Galileo), protože meteorologické jevy se nepohybují takto pravidelně. Galileo, který nepřijímal Tychonův geo-heliocentrický systém obhajovaný jezuitskými astronomy, nemohl Grassiho hypotézu uznat, nebot ta se o geo-heliocentrický systém naopak opírala (a předpokládala tedy nehybnost Země). Nehybností Země bylo však $\mathrm{v}$ rámci Tychonova systému možné vysvětlit pohyb komet, který se na rozdíl od retrográdního pohybu planet jako vůči Zemi retrográdní nejeví. Uznat nehybnost Země by však znamenalo popřít Koperníkův heliocentrický systém, který Galileo naopak zastával. Proto zvolil klasičtější řešení a vášnivě obhajoval tezi, že se komety jako planety zkrátka nechovají.

Touto úvahou se dostáváme $\mathrm{k}$ funkci teleskopu a $\mathrm{k}$ reálnosti obrazů, které prŕístroj poskytuje. Daniel Špelda v úvodu přehledně shrnuje, jak řešil otázku smyslů a jejich vztahu ke světu Aristoteles. Vzhledem k jeho teleologickému pojetí vesmíru nemůže existovat nic, co by se smysly nedalo zachytit, jelikož jejich účelem je poskytovat adekvátní obraz skutečnosti. Zvětšení a zmenšení je irelevantní, protože jakkoliv malá část celku je stejné podstaty jako část větší, takže nese stejnou informaci. Smysly jsou s okolním světem v dokonalém souladu, proto je poslední věcí vesmíru zároveň poslední vnímatelná věc, což nás vrací ke sféře stálic, $\mathrm{z}$ níž se tak stává hranice nejen naší zkušenosti, ale rovněž hranice vesmíru. Teleskop a později i mikroskop tuto představu nevratně narušili. Daniel Špelda připomíná, že ani Galileo zprvu nepočítal $s$ tím, co všechno může dalekohled přinést a že jej měl $\mathrm{v}$ úmyslu používat pouze jako praktický nástroj ve vojenství. Svůj postoj musel Galileo přehodnotit, rozumění vesmíru totiž dalekohled dokonale relativizoval.

$\mathrm{O}$ užitečnosti dalekohledu byl ostatně přesvědčený i Orazio Grassi. Jeho spor s Galileem se však soustředil na interpretaci přiblížení jevů objektů nacházejících se ve velkých vzdálenostech od pozorovatele. Právě jezuité pomohli vymanit obrazy poskytované čočkami z oblasti jevů přirozené magie a dali jim autoritu skutečnosti. V Prubiři je zajímavé sledovat, jak obě strany používají stejného nástroje $\mathrm{k}$ podložení svého závěru. Grassi argumentuje neprrímou úměrou: čím vzdálenější jsou pozorované objekty, tím jsou méně zvětšené. $Z$ toho plyne závěr, že komety, které jsou zvětšené málo, musí být hodně vzdálenými objekty, tedy určitě supralunárními.

Grassi v tomto argumentu využil svých poznatků o záření hvězd a planet a zjištění, že vzdálené objekty dalekohled nezvětšuje. Proti tomu však Galileo namítá, že se Grassi nechal zmást zdánlivou září těles, jež samotná tělesa opticky zakrývá. Dalekohled naše pozorování naopak zostří natolik, že je záření (hříva) překryto vlastním tělesem. Pozorování je tak přiměřenější, protože část jevící se záře není skutečnou vlastností těles, 
nýbrž je vyvolávána lomem paprsků na okrajích vlhkého lidského oka. Tuto záři tedy dalekohled nezvětšuje, a tak je podle Galilea Grassiho argument o supralunární dráze komet lichý.

Galileo byl oproti Grassimu přesvědčen o tom, že zvětšení dalekohledu je konstantní. Proto je potřeba počítat i s tím, že stálice jsou zvětšovány stejně jako Měsíc. Pokud se to tak pozorovateli nejeví, pak je příčiny jevu potřeba hledat jinde než v argumentu Grassiho. Grassi si totiž představoval, že dalekohled je nástroj nedokonalý, tedy nedokonale účinný. Nedokonalé účinky se projevují právě na vzdálených objektech, proto nejsou patřičně zvětšeny. Galileo byl však s konstrukcí dalekohledu obeznámen natolik, aby si uvědomil vztah mezi velikostí čočky, zornicí lidského oka a jasností. Vladimír Štefl ve své studii připomíná, že problém malého zvětšení komet dalekohledem byl jednou z klíčových záležitostí astronomie první čtvrtiny 17. století.

Jak již bylo zmíněno, Galileo nepočítal s tím, že by pozorování prostřednictvím teleskopu vedla $\mathrm{k}$ tak dalekosáhlým konceptuálním proměnám. Objevení nových, lidským okem nezachytitelných objektů odhalilo, opět proti Aristotelově přesvědčení, nedokonalost našich smyslů. Proto se Galileo přiklonil $\mathrm{k}$ atomistickému rozdělení kvalit, jež později rozpracoval Locke jako primární a sekundární. Připomeňme zde jen to, že tělesům jsou vlastní v prvé řadě primární kvality, jež kvalitativně určují částice, ze kterých jsou tělesa složena. Tyto kvality jsou kvantifikovatelné, jelikož jsou vyjádřitelné matematicky (velikost, pohyb, tvar, počet). „Převedení kvalitativní rozmanitosti na stranu vnímajícího subjektu významně podpořilo uplatnění matematiky na zkoumání př́rody, protože se předpokládalo, že primární kvality - které skutečně náleží předmětům - jsou kvantifikovatelné. Počínající moderní věda definovala předem svůj předmět bádání tím, že ho redukovala na soubor kvantifikovatelných objektů. Tento proces, který byl jedním $\mathrm{z}$ důvodů triumfu evropské vědy, začal u Galilea, který naprŕílad při zkoumání volného pádu také chápal padající tělesa jako idealizované objekty, které lze popsat pomocí matematiky." (44-45) Nikoli tradice, ale vesmír je pravou knihou, v níž je třeba číst, a číst v ní lze jen jazykem geometrie či matematiky.

Vladimír Štefl v úvodní studii vyzdvihuje Grassiho aristotelský výrok, že zvětšení prostřednictvím dalekohledu lze považovat za „přechod z nebytí do bytí“. Galileo však ve svém textu explicitně formuluje představu tajuplného vesmíru, $\mathrm{z}$ něhož se nám odkrývá jen pramálo a mnohé našemu poznání naopak uniká. Neexistuje tedy jen to, co dokáží zachytit naše smysly. Teleskop nám leccos odkryl, otázkou však zůstává, co odkrýt nedokázal. 
A nic $\mathrm{z}$ toho neznamená, že bychom měli na poznávání rezignovat, naopak - měli bychom pracovat na zdokonalování přístrojů, které nám dovolí pozorování či měření zpř̌esňovat.

Výsledkem je, jak uvádí Vladimír Štefl, že „dalekohledem Galileo nalezl velký počet ,nových' hvězd, několik desítek až stovek, konkrétně v hvězdných polích Orionu či v hvězdokupě Plejády. Učinil tak první krok k výzkumu mlhovin a hvězdokup." (65) Jeho pozorování vedlo k tomu, že se musela proměnit představa o sféře stálic. Hypotéza o tom, že jsou hvězdy v této sféře ve stejné vzdálenosti od Země, byla dále neudržitelná.

Jak známo, Galileo byl stoupencem velice opatrně přijímané teorie Koperníka. V Prubiŕi se však kolem tohoto tématu snaží chodit po špičkách. Koperníkovo učení bylo na černé listině, takže se nesmělo nijak šírit a ani Galileo jej tedy nesměl obhajovat. Tvrdí, že jeho argumentace nejen o kometách, ale o všech jevech, které diskuzi provázejí, nemůže vycházet z Ptolemaiových či Koperníkových prací. Ani jeden z nich se totiž podle Galilea nezabýval vzdálenostmi, velikostmi, pohybem nebo trajektorií komet. Z kontextu pak vyplývá, že částečně pod tímto tlakem Galileo přešel ke zpochybnění autorit vůbec. „Krom toho se mi zdá, že v Sarsim rozpoznávám pevné přesvědčení, že je při filosofování nezbytné opř́t se o názory nějakého slavného autora, jako kdyby naše mysl měla zůstat neplodná a neúrodná, kdyby se nespojila s uvažováním někoho dalšího." (126) Vesmír však mluví sám za sebe, je jen třeba naučit se v něm číst (právě po tomto citátu následuje slavná pasáž o knize př́rody napsané jazykem matematiky a geometrie).

$\mathrm{V}$ předcházejícím textu jsme vybrali jen některá témata $\mathrm{z}$ rozsáhlého dopisu. Mezi další problémy, jež se $\mathrm{v}$ polemice objevují, najdeme např. úvahy o velikostech, pohybu a kvalitě nebeských sfér, o halových jevech, barvách a lomech světla, přilnavosti těles, dokonalosti povrchu vesmírných těles (a tedy o jejich dokonalosti), o vztažných soustavách, prokazatelnosti vybraných experimentů, síle argumentu, správném použití nákresů a geometrických důkazů nebo také o rovnoměrném prrímém pohybu. Díky čtivě a přehledně koncipovaným úvodním studiím Daniela Speldy a Vladimíra Štefla je Galileův Prubiř př́stupný nejen filosofům, historikům vědy, fyzikům či astronomům. Čtenáři poskytují značný komfort a umožňují Galilea číst bez nutnosti složitě dohledávat souvislosti a doplňovat znalosti, bez nichž by se mu dalo rozumět jen částečně. Kvalitě celé edice určitě výrazně napomohla Markéta Ledvoňová nejen svým překladem (společně s Janou Malou) Prubíre z latiny a italštiny, ale také svými studiemi v rámci prrípravy disertace a samotnou dizertací, k níž Daniel Špelda často odkazuje. V prŕpadě, že by se čtenář zabýval tématikou Galileových objevů detailněji, 
má k dispozici široký poznámkový aparát, který autoři obou úvodních studií připojili ke svým textům. Kontextuálními poznámkami je pak doplněn i vlastní text Prubiře, v němž se Galileo ukazuje nejen jako nositel vědecké revoluce 17. století, ale také jako myslitel hledající a chybující, člověk s energií a zápalem. ${ }^{6}$

\section{Bibliografie:}

Galilei, Galileo. Prubiř. Překlad Markéta Ledvoňová a Jana Malá. Odborná spolupráce a komentáře Markéta Ledvoňová, Daniel Špelda a Vladimír Štefl. Praha: Togga, 2020.

Galilei, Galileo a Johannes Kepler. Hvězdný posel / Rozprava s Hvězdným poslem. Překlad Alena Hadravová. Př́ibram: Pistorius \& Olšanská, 2016.

Ledvoňová, Markéta. „Galileovy cesty k nové vědě.“ Disertační práce, Masarykova univerzita, 2019.

${ }^{6}$ Tomu se ve své dizertaci podrobněji věnuje Markéta Ledvoňová, „Galileovy cesty k nové vědě“ (disertační práce, Masarykova univerzita, 2019). 